\title{
Selection of peptides binding to metallic borides by screening M13 phage display libraries
}

\author{
Martin Ploss', Sandra J Facey ${ }^{1}$, Carina Bruhn², Limor Zemel ${ }^{3}$, Kathrin Hofmann², Robert W Stark ${ }^{3}$, \\ Barbara Albert ${ }^{2}$ and Bernhard Hauer ${ }^{1 *}$
}

\begin{abstract}
Background: Metal borides are a class of inorganic solids that is much less known and investigated than for example metal oxides or intermetallics. At the same time it is a highly versatile and interesting class of compounds in terms of physical and chemical properties, like semiconductivity, ferromagnetism, or catalytic activity. This makes these substances attractive for the generation of new materials. Very little is known about the interaction between organic materials and borides. To generate nanostructured and composite materials which consist of metal borides and organic modifiers it is necessary to develop new synthetic strategies. Phage peptide display libraries are commonly used to select peptides that bind specifically to metals, metal oxides, and semiconductors. Further, these binding peptides can serve as templates to control the nucleation and growth of inorganic nanoparticles. Additionally, the combination of two different binding motifs into a single bifunctional phage could be useful for the generation of new composite materials.

Results: In this study, we have identified a unique set of sequences that bind to amorphous and crystalline nickel boride $\left(\mathrm{Ni}_{3} \mathrm{~B}\right)$ nanoparticles, from a random peptide library using the phage display technique. Using this technique, strong binders were identified that are selective for nickel boride. Sequence analysis of the peptides revealed that the sequences exhibit similar, yet subtle different patterns of amino acid usage. Although a predominant binding motif was not observed, certain charged amino acids emerged as essential in specific binding to both substrates. The 7-mer peptide sequence LGFREKE, isolated on amorphous $\mathrm{Ni}_{3} \mathrm{~B}$ emerged as the best binder for both substrates. Fluorescence microscopy and atomic force microscopy confirmed the specific binding affinity of LGFREKE expressing phage to amorphous and crystalline $\mathrm{Ni}_{3} \mathrm{~B}$ nanoparticles.

Conclusions: This study is, to our knowledge, the first to identify peptides that bind specifically to amorphous and to crystalline $\mathrm{Ni}_{3} \mathrm{~B}$ nanoparticles. We think that the identified strong binding sequences described here could potentially serve for the utilisation of M13 phage as a viable alternative to other methods to create tailor-made boride composite materials or new catalytic surfaces by a biologically driven nano-assembly synthesis and structuring.
\end{abstract}

\section{Background}

The diverse group of transition metal borides comprises compounds that exhibit or combine interesting physical properties such as semiconductivity, ferromagnetism, hardness, thermal and mechanical stability and oxidation resistance [1]. Some of the binary, ternary, and quaternary metal borides are even superconducting or represent some of the strongest permanent magnets [2,3]. Because of the high melting point of boron, the traditional

\footnotetext{
* Correspondence: bernhard.hauer@itb.uni-stuttgart.de

'Institute of Technical Biochemistry, University of Stuttgart, Allmandring 31,

70569 Stuttgart, Germany

Full list of author information is available at the end of the article
}

synthesis of metal borides does not result in nanoscale or nanostructured products. As an alternative, a room temperature synthesis of nickel boride nanoparticles via hydrolysis of $\mathrm{NaBH}_{4}$ has been reported [4-7]. Biological systems, on the other hand, can synthesise materials under mild and environmentally benign conditions [8]. Nickel borides like $\mathrm{Ni}_{3} \mathrm{~B}, \mathrm{Ni}_{2} \mathrm{~B}$ or $\mathrm{NiB}$ are considered to exhibit catalytic activity in all kinds of reduction reactions, and hydrogenation reactions [9-15]. Like iron borides they are expected to exhibit paramagnetism, ferro- or superparamagnetism $[16,17]$. The electrical conductivities of different nickel borides vary with their boron content. Thus, the nickel-boron system represents an interesting class of

\section{Biomed Central}


compounds for a model study on peptide-boride interactions and the potential of bio-modified inorganic solids. Until now nothing is known about the interaction between boron-containing materials and peptides, although peptides binding to solid surfaces have been extensively exploited for other chemical systems in nanoscale science because of their material selective properties [18-20]. To select for peptides that are capable of interacting with inorganic materials, phage peptide display is a powerful technique [21]. Phage display is a selection technique in which a combinatorial library of random peptides $\left(\sim 10^{9}\right)$ is expressed as a fusion with an M13 phage coat protein (usually p3), resulting in the display of the fused peptide on the surface of the phage particle. Selection of the desired peptides, which is usually a random 7- or 12-amino acid peptide, is achieved by multiple rounds of target binding, elution and amplification, a process known as biopanning (or panning). Because the DNA sequence for the displayed peptide is genetically fused to the $\mathrm{p} 3$ gene, the amino acid sequence of the phage-displayed peptide is readily obtained by sequencing the $\mathrm{p} 3$ encoding DNA.

Phage display has been used to identify peptides which specifically bind to metals like $\mathrm{Ag}$, and $\mathrm{Pd}$, and various inorganic materials like $\mathrm{ZnO}, \mathrm{SiO}_{2}, \mathrm{TiO}_{2}, \mathrm{ZnS}$, and $\mathrm{CdS}$ [22-29]. In the last few years, specific binding peptides to nickel have also been described [30-32]. Up to now, no specific binding peptides have been identified for borides in general, neither nanostructured nor bulk material, or more specifically nickel boride nanoparticles. The identification of such a selective binding peptide sequence would be a first, significant step towards peptide-modified boride materials and composites. Such linkers would help to make boride particles available for biological systems and allow for a tuning of the properties of borides using a biological peptide-enabled nanoassembly process.

Since to our knowledge no binding peptides to boride nanoparticles are described in the literature, our aim of this research was to identify peptides that bind specifically to metallic borides. This constitutes the first step in order to combine two different binding motifs e.g. a metallic and a ceramic boride into a single bifunctional phage or into a synthetic bifunctional peptide. This would be useful for the generation of new boride composite materials in which the physical properties of two different borides are unified which is until now not combinable. Peptides were selected after several rounds of screening with a commercial phage library. Several $\mathrm{Ni}_{3} \mathrm{~B}$-binding peptides were selected using nanoparticles of amorphous and crystalline $\mathrm{Ni}_{3} \mathrm{~B}$ as targets. From the initial library, we identified ten phages that exhibit selective binding to either amorphous or crystalline or both using titer count analysis, fluorescence and atomic force microscopy.

\section{Results and discussion}

\section{Isolation of $\mathrm{Ni}_{3} \mathrm{~B}$-binding peptides}

To identify $\mathrm{Ni}_{3} \mathrm{~B}$-binding peptides, a commercial available M13 bacteriophage display library (Ph.D.-7; New England Biolabs) was screened against amorphous and crystalline $\mathrm{Ni}_{3} \mathrm{~B}$ nanoparticles. In the Ph.D.-7 library, random linear heptapeptides are displayed as $\mathrm{N}$-terminal fusions to the minor coat protein $\mathrm{p} 3$ of M13. The M13 phage p3 constructs used in the screening selection have five copies of the peptide displayed on the one end of the phage particle. Five rounds of biopanning were conducted for each of the amorphous and crystalline $\mathrm{Ni}_{3} \mathrm{~B}$ substrates. Each biopanning round involved the steps of phage binding, removal of weak binding affinity phage by washing, and elution of bound phage by a rapid $\mathrm{pH}$ decrease. More stringent washing conditions were used in the additional rounds of panning. A $0.3 \%$ TBST wash solution was used to remove phage with low binding affinity to $\mathrm{Ni}_{3} \mathrm{~B}$ during the second round, whereas $0.5 \%, 0.6 \%$, and $0.8 \%$ TBST wash solutions were used for the third, fourth, and fifth round, respectively. A total of 58 phage clones were selected and analysed by DNA sequencing after the fourth and fifth round of biopanning against amorphous and crystalline $\mathrm{Ni}_{3} \mathrm{~B}$ substrates. For amorphous $\mathrm{Ni}_{3} \mathrm{~B}$ substrates, 30 peptides were identified coding for 15 different peptide sequences (designated with an A for amorphous). A summary of the peptides identified from biopanning against amorphous $\mathrm{Ni}_{3} \mathrm{~B}$ is provided in Table 1 . In the case of the biopanning against crystalline $\mathrm{Ni}_{3} \mathrm{~B}$ substrates, 28 peptides were isolated coding for 28 different peptide sequences (designated with a $\mathrm{C}$ for crystalline) shown in Table 2 . The fact that all the peptides which were identified for crystalline $\mathrm{Ni}_{3} \mathrm{~B}$ are different, could be an indication of a more complex surface structure for crystalline $\mathrm{Ni}_{3} \mathrm{~B}$ nanoparticles than for amorphous $\mathrm{Ni}_{3} \mathrm{~B}$ nanoparticles. Interestingly, one peptide sequence, ANHQSAN, termed $\mathrm{A} 6 / \mathrm{C} 28$, was isolated from both, amorphous and crystalline, $\mathrm{Ni}_{3} \mathrm{~B}$ substrates. While most of the peptides, especially identified for the crystalline $\mathrm{Ni}_{3} \mathrm{~B}$ substrate, were isolated only once, for the amorphous substrate the peptide A1 was isolated eight-times, A2 six-times, and A3 four-times, respectively.

\section{Characteristics of the identified binding peptides}

Due to the fact that cysteines interfere with the p3mediated M13 infection process, no cysteines were present in the identified binding peptides [33]. The binding peptides showed approximately three-times more positively charged residues ( $\mathrm{K}, \mathrm{R}$, and $\mathrm{H}$ ) than negatively charged residues (D and E) (Table 3). Compared with the peptides binding to amorphous $\mathrm{Ni}_{3} \mathrm{~B}$, the binding peptides to crystalline nickel boride show a two-times higher occurrence of the positively charged amino acids arginine and lysine, and a three-times higher occurrence 
Table 1 Summary of the isolated binding peptides to amorphous $\mathrm{Ni}_{3} \mathrm{~B}$

\begin{tabular}{|c|c|c|c|c|c|c|}
\hline \multirow[t]{2}{*}{ Peptide } & \multirow[t]{2}{*}{ Frequency } & \multirow[t]{2}{*}{ Sequence } & \multicolumn{3}{|c|}{ Number of functional amino acid residues } & \multirow[t]{2}{*}{$\mathrm{pl}$} \\
\hline & & & Basic & Acidic & Hydrophobic & \\
\hline A4 & $1 / 30$ & SEIVDNH & 1 & 2 & 2 & 4.35 \\
\hline $\mathrm{A} 1$ & $8 / 30$ & TNLTLAS & 0 & 0 & 3 & 5.19 \\
\hline $\mathrm{A} 2$ & $6 / 30$ & GALPNNL & 0 & 0 & 3 & 5.52 \\
\hline A8 & $1 / 30$ & NVNSTSF & 0 & 0 & 2 & 5.52 \\
\hline A9 & $1 / 30$ & SPDTVQK & 1 & 1 & 1 & 5.55 \\
\hline A10 & $1 / 30$ & GNRLSAD & 1 & 1 & 2 & 5.84 \\
\hline A7 & $1 / 30$ & LGFREKE & 2 & 2 & 2 & 6.14 \\
\hline $\mathrm{A} 11$ & $1 / 30$ & TQVYHPM & 1 & 0 & 3 & 6.40 \\
\hline A6 & $1 / 30$ & ANHQSAN & 1 & 0 & 2 & 6.19 \\
\hline A5 & $1 / 30$ & TNSSFHK & 2 & 0 & 1 & 8.44 \\
\hline $\mathrm{A} 12$ & $1 / 30$ & NTVIYQK & 1 & 0 & 3 & 8.59 \\
\hline A13 & $1 / 30$ & HVQYWQF & 2 & 0 & 3 & 8.75 \\
\hline $\mathrm{A} 3$ & $4 / 30$ & SLAVSRS & 1 & 0 & 3 & 9.47 \\
\hline A14 & $1 / 30$ & VSVNSRT & 1 & 0 & 2 & 9.72 \\
\hline A15 & $1 / 30$ & RLLNPWI & 1 & 0 & 4 & 9.75 \\
\hline
\end{tabular}

of histidine, respectively. Although the distribution of charged amino acids in the library is comparable in frequency, the increased abundance of these amino acids within the identified sequences could be possibly attributed to the surface composition of the nickel borides. The characterisation of the surface of different amorphous nickel borides by Okamoto et al. and Caputo et al. by X-ray photoelectron spectroscopy (XPS) and X-ray diffraction (XRD), respectively, revealed that the electron densities on nickel are increased by electron transfer from boron to the metal $[6,34]$. Based on the shift of the charge, specific binding peptides could therefore interact with the nickel boride substrates via electrostatic interactions. The majority of the peptides identified on $\mathrm{Ni}_{3} \mathrm{~B}$ prevalently possess alanine, leucine, proline, serine and threonine residues (Figure 1) which is a consequence of the amino acid distribution of the applied phage display library. In addition, the binding peptides identified on amorphous $\mathrm{Ni}_{3} \mathrm{~B}$ possess 2.5-times more asparagine residues as compared with the peptides identified on crystalline $\mathrm{Ni}_{3} \mathrm{~B}$. This is vice versa with proline residues binding to crystalline $\mathrm{Ni}_{3} \mathrm{~B}$. The strong presence of asparagine in the peptide sequences binding to amorphous $\mathrm{Ni}_{3} \mathrm{~B}$, and asparagine and histidine in the peptide sequences binding to crystalline $\mathrm{Ni}_{3} \mathrm{~B}$ suggests that the binding between the $\mathrm{Ni}_{3} \mathrm{~B}$ and peptides could furthermore occur via hydrogen bonding interactions. The almost complete absence of tryptophan, phenylalanine, and methionine residues is also due to the low frequencies of these amino acids within the library. An amino acid position consensus was not evident from the 7-mer library screening of $\mathrm{Ni}_{3} \mathrm{~B}$ nanoparticles as substrates.
However, besides the predominantly hydrophobic amino acids ( $\mathrm{A}$ and $\mathrm{L}$ ) and hydrophilic amino acids ( $\mathrm{S}$ and $\mathrm{T}$ ) the variety of amino acids with charged side groups implies that these groups could be essential in specific binding to both substrates via electrostatic interactions. The $\mathrm{Ni}_{3} \mathrm{~B}$-binding peptides identified possess calculated theoretical isoelectric points $(\mathrm{p} I)$ ranging from strongly acidic (4.0) to highly basic (9.75). 60\% of the peptides binding to amorphous $\mathrm{Ni}_{3} \mathrm{~B}$ show a $\mathrm{p} I$ value $<7.5$ while $40 \%$ of the peptides have $\mathrm{p} I>7.5$. $57 \%$ of the peptides binding to crystalline $\mathrm{Ni}_{3} \mathrm{~B}$ show a $\mathrm{p} I$ value $<7.5$ and $43 \%$ of the peptides have $\mathrm{p} I>7.5$. Therefore the identified peptides can be grouped into the categories acidic (pI 3.0 - 5.9; 35.7\% of the peptides), neutral (pI $6.0-8.9$; $52.4 \%$ of the peptides), and basic (pI $9.0-12 ; 11.9 \%$ of the peptides), respectively.

\section{Relative binding affinity experiments}

Because of the heterogeneity of all of the identified binding peptides and the absence of a distinctive binding motif, the binding strength of each of the 42 identified peptides to amorphous (Figure $2 \mathrm{~A}$ ) and crystalline (Figure $2 \mathrm{~B}$ ) $\mathrm{Ni}_{3} \mathrm{~B}$ was determined by titer assays. Since previously binding affinity experiments at $\mathrm{pH} 5$ or $\mathrm{pH} 9$ with a subset of the identified binding peptides showed no increase in binding affinity (data not shown) the relative binding affinity experiments were carried out at $\mathrm{pH} 7$. As a control to verify that the peptide was the interactor of interest, M13KE wild-type (M13wt) phage without a random peptide insert were compared in the same manner as the peptide clones. As presented in Figure 2A, most of the phage clones, except $\mathrm{C} 2$ and $\mathrm{C} 17$, bind to amorphous $\mathrm{Ni}_{3} \mathrm{~B}$ with greater affinity than 
Table 2 Summary of the isolated binding peptides to crystalline $\mathrm{Ni}_{3} \mathrm{~B}$

\begin{tabular}{|c|c|c|c|c|c|c|}
\hline \multirow[t]{2}{*}{ Peptide } & \multirow[t]{2}{*}{ Frequency } & \multirow[t]{2}{*}{ Sequence } & \multicolumn{3}{|c|}{ Number of functionnal amino acid residues } & \multirow[t]{2}{*}{$\mathrm{pl}$} \\
\hline & & & Basic & Acidic & Hydrophobic & \\
\hline $\mathrm{C} 15$ & $1 / 28$ & LEQTPMF & 0 & 1 & 3 & 4.00 \\
\hline $\mathrm{C} 16$ & $1 / 28$ & ELTQISS & 0 & 1 & 2 & 4.00 \\
\hline $\mathrm{C} 2$ & $1 / 28$ & SDPQTHT & 1 & 1 & 0 & 5.06 \\
\hline $\mathrm{C} 3$ & $1 / 28$ & TPPLLSP & 0 & 0 & 2 & 5.19 \\
\hline $\mathrm{C} 17$ & $1 / 28$ & MNHAESY & 1 & 1 & 2 & 5.22 \\
\hline $\mathrm{C} 18$ & $1 / 28$ & VPSLTPT & 0 & 0 & 2 & 5.49 \\
\hline $\mathrm{C} 4$ & $1 / 28$ & VPIPYLP & 0 & 0 & 4 & 5.49 \\
\hline C19 & $1 / 28$ & DPYNRIN & 1 & 1 & 2 & 5.84 \\
\hline $\mathrm{C} 20$ & $1 / 28$ & RTFDAIS & 1 & 1 & 3 & 5.84 \\
\hline $\mathrm{C} 21$ & $1 / 28$ & YELVLPK & 1 & 1 & 4 & 6.00 \\
\hline $\mathrm{C} 5$ & $1 / 28$ & ETFPARG & 1 & 1 & 2 & 6.10 \\
\hline $\mathrm{C} 13$ & $1 / 28$ & GPVNHQL & 1 & 0 & 2 & 6.74 \\
\hline $\mathrm{C} 22$ & $1 / 28$ & LNHVLPA & 1 & 0 & 4 & 6.74 \\
\hline $\mathrm{C} 23$ & $1 / 28$ & HAMRTEP & 2 & 1 & 2 & 6.75 \\
\hline $\mathrm{C} 6$ & $1 / 28$ & ATSTAHA & 1 & 0 & 3 & 6.79 \\
\hline $\mathrm{C} 28$ & $1 / 28$ & ANHQSAN & 1 & 0 & 2 & 6.79 \\
\hline $\mathrm{C} 10$ & $1 / 28$ & SYTKLI-IL & 2 & 0 & 3 & 8.33 \\
\hline $\mathrm{C} 1$ & $1 / 28$ & SPPKSNA & 1 & 0 & 1 & 8.47 \\
\hline C9 & $1 / 28$ & SASKVHN & 2 & 0 & 2 & 8.49 \\
\hline $\mathrm{C} 24$ & $1 / 28$ & SPSTHWK & 2 & 0 & 1 & 8.49 \\
\hline $\mathrm{C} 25$ & $1 / 28$ & WNAKYTL & 1 & 0 & 4 & 8.59 \\
\hline $\mathrm{C} 12$ & $1 / 28$ & YQWPAR & 1 & 0 & 4 & 8.75 \\
\hline $\mathrm{C} 26$ & $1 / 28$ & GDPKAAR & 2 & 1 & 2 & 8.75 \\
\hline C11 & $1 / 28$ & GDHSRHK & 4 & 1 & 0 & 8.76 \\
\hline C14 & $1 / 28$ & AGLPKHQ & 2 & 0 & 2 & 8.80 \\
\hline $\mathrm{C} 27$ & $1 / 28$ & STFNSRV & 1 & 0 & 2 & 9.47 \\
\hline $\mathrm{C} 8$ & $1 / 28$ & VHTNPSR & 2 & 0 & 1 & 9.73 \\
\hline $\mathrm{C7}$ & $1 / 28$ & GASATRT & 1 & 0 & 2 & 9.75 \\
\hline
\end{tabular}

does the M13wt phage, which shows a binding affinity of $2 \times 10^{7} \mathrm{pfu} / \mathrm{ml}$ with amorphous $\mathrm{Ni}_{3} \mathrm{~B}$. Compared with the M13wt phage, 9 out of 42 identified peptides (see arrows in Figure 2A) bound on average 100-times and 28 on average ten-times more efficiently to amorphous $\mathrm{Ni}_{3} \mathrm{~B}$ than the wild-type, verifying that binding to the substrate was a result of the peptide sequence and not due to non-specific phage coat protein interactions. The peptides A7, C12, and C15 (see arrows in Figure 2B) bound on average 1000-times more efficiently to crystalline $\mathrm{Ni}_{3} \mathrm{~B}$ as compared to the M13wt phage, which shows a binding affinity of $5 \times 10^{6} \mathrm{pfu} / \mathrm{ml}$. Interestingly, the phage clone $\mathrm{A} 7$ identified for amorphous $\mathrm{Ni}_{3} \mathrm{~B}$ shows a higher binding affinity to crystalline $\mathrm{Ni}_{3} \mathrm{~B}$ than most of the $\mathrm{Ni}_{3} \mathrm{~B}$-binding peptides (C1-C11, C13-C14, and $\mathrm{C} 16-\mathrm{C} 28$ ) identified for crystalline $\mathrm{Ni}_{3} \mathrm{~B}$. In addition, the amorphous $\mathrm{Ni}_{3} \mathrm{~B}$-binding peptides A8-A10 show a higher binding affinity to crystalline $\mathrm{Ni}_{3} \mathrm{~B}\left(\geq 10^{9} \mathrm{pfu} / \mathrm{ml}\right)$ than several binding peptides found for crystalline $\mathrm{Ni}_{3} \mathrm{~B}$ specifically (i.e. C1-C11, C13-C14, C16-C24, and C27-28). The relative binding affinity experiments revealed a set of several strong binders $\left(>10^{9} \mathrm{pfu} / \mathrm{ml}\right)$ for amorphous (A1A3, A7, C4, C9, C13, C15, and C24) and crystalline (A7, $\mathrm{C} 12$, and $\mathrm{C} 15$ ) substrates (Table 4). The phages displaying the peptides A7 and $\mathrm{C} 15$ emerged as the best binders for both substrates.

\section{Competitive binding assays of the best binding peptides}

The competitive binding assay represents a method to determine the most selective binding peptide sequence from a large subset of phage display results [35]. To identify a specifically recognised structural correlation between the surfaces of amorphous and crystalline $\mathrm{Ni}_{3} \mathrm{~B}$ nanoparticles, the individual phage clones of the nine 


\begin{tabular}{lll}
$\begin{array}{l}\text { Table } 3 \text { Occurrences of amino acids of the isolated } \mathbf{N i}_{3} \mathbf{B} \\
\text { binding peptides }\end{array}$ \\
\hline Amino acid & Averaged quantity of occurrences per heptapeptide \\
\cline { 2 - 3 } & Amorphous & Crystalline \\
\hline A & 0.70 & 0.68 \\
R & 0.20 & 0.36 \\
N & 1.00 & 0.43 \\
D & 0.10 & 0.18 \\
C & 0.00 & 0.00 \\
Q & 0.20 & 0.25 \\
E & 0.10 & 0.21 \\
G & 0.27 & 0.21 \\
H & 0.17 & 0.50 \\
I & 0.10 & 0.14 \\
L & 1.20 & 0.50 \\
K & 0.13 & 0.29 \\
M & 0.03 & 0.11 \\
F & 0.10 & 0.14 \\
P & 0.30 & 0.82 \\
S & 1.00 & 0.75 \\
T & 0.73 & 0.68 \\
W & 0.07 & 0.07 \\
Y & 0.10 & 0.25 \\
V & 0.40 & 0.36 \\
\hline
\end{tabular}

strongest binders (A1-A3, A7, C4, C9, C13, C15, and C24) to amorphous $\mathrm{Ni}_{3} \mathrm{~B}$ as determined by the relative binding affinity experiments were diluted into a single mini-phage library. The mini-phage library was then screened against amorphous or crystalline $\mathrm{Ni}_{3} \mathrm{~B}$ substrates. To receive better statistical results, the competitive binding assays were repeated three-times. After a single panning experiment, the strongly bound phages were isolated and a total of 58 phage clones were randomly selected and analysed by DNA sequencing to identify the strongest binding peptides. In Tables 5 and 6 the most abundant sequence indicates the strongest binding peptide to amorphous and crystalline $\mathrm{Ni}_{3} \mathrm{~B}$, respectively. Among the 58 randomly chosen plaques, the phage displaying the A7 peptide LGFREKE has the strongest binding affinity to amorphous (seventeentimes, $\sim 58 \%$ ) and crystalline (thirteen-times, $\sim 45 \%$ ) $\mathrm{Ni}_{3} \mathrm{~B}$. Interestingly, the amino acids lysine, arginine, and glutamic acid were shown to have a pronounced adhesion of their charged side groups to amorphous $\mathrm{Si}_{3} \mathrm{~N}_{4}$ and $\mathrm{SiO}_{2}$ under aqueous conditions [36]. It was also reported, that the surface of amorphous $\mathrm{Si}_{3} \mathrm{~N}_{4}$ may present negative sites in solution [37]. Therefore substrates, possessing negatively surface charges in aqueous solution with $\mathrm{pH}$ values less than the intrinsic $\mathrm{pK}_{\mathrm{a}}$ of the side chain of a basic amino acid, a peptide containing basic amino acids will be positively charged at these groups and will provide an attractive interaction to the given surface [36]. In aqueous solutions with higher $\mathrm{pH}$ values than the intrinsic $\mathrm{pK}_{\mathrm{a}}$ of the side chain of an acidic amino acid, a peptide containing acidic amino acids will be negatively charged at these groups. Based on these facts, the best binder A7 (LGFREKE) possesses in solution at $\mathrm{pH} 7$ an alternating series of positively and negatively charged side chains in its peptide sequence which could be responsible for an interaction between the charge depleted boron and the electrons accumulated on the nickel side of amorphous and crystalline $\mathrm{Ni}_{3} \mathrm{~B}$ nanoparticles. In contrast, the 7-mer peptide sequence TNLTLAS, termed A1, which emerged as the dominant amorphous $\mathrm{Ni}_{3} \mathrm{~B}$ binder in the initial screening, possesses no charged side chain. The lack of electrostatic interactions might contribute to the observed fact, that it does not show the highest frequency in the competitive assay.

\section{Fluorescence microscopy of $\mathrm{Ni}_{3} \mathrm{~B}-\mathrm{M} 13$ complex}

The binding of phage displaying the A7 peptide LGFREKE to amorphous and crystalline $\mathrm{Ni}_{3} \mathrm{~B}$ nanoparticles was confirmed by fluorescence microscopy. Amplified phage displaying the LGFREKE peptide were incubated either with amorphous or crystalline $\mathrm{Ni}_{3} \mathrm{~B}$ nanoparticles and then washed to remove the nonspecifically bound phage particles. The samples were then dyed using a fluorescently tagged anti-M13 monoclonal antibody and washed again to eliminate nonspecifically bound anti-M13 antibodies. The fluorescence confocal images in Figure $3 \mathrm{~A}$ and $\mathrm{C}$ show the LGFREKE displaying phage binding to the surface of amorphous and crystalline $\mathrm{Ni}_{3} \mathrm{~B}$ nanoparticles, respectively. Considerable fluorescence emits from the surfaces of the LGFREKE phage- $\mathrm{Ni}_{3} \mathrm{~B}$ nanoparticles. Although the relative binding affinity experiments showed an unspecific binding of the wild-type phage to the $\mathrm{Ni}_{3} \mathrm{~B}$ substrates, the control experiments (Figure 3E and G) showed no fluorescence. This could be due to the fact that the concentration of bound phage is below the detection limit.

\section{AFM measurements}

To verify the interaction between M13 phage displaying the $\mathrm{A} 7$ peptide on the $\mathrm{p} 3$ coat protein and $\mathrm{Ni}_{3} \mathrm{~B}$ particles, AFM measurements of phage bound to amorphous and crystalline $\mathrm{Ni}_{3} \mathrm{~B}$ particles were carried out (Figure 4). The modified M13 phage were incubated either with amorphous or crystalline nanoparticles as shown in Figure 4A and B, respectively. As shown in Figure 4A and B the height of the colour scale exceeds the height of the particles. This colour scale was chosen to show the 100-nm-thick particles together with the 6-nm-thick phage. Individual phage 


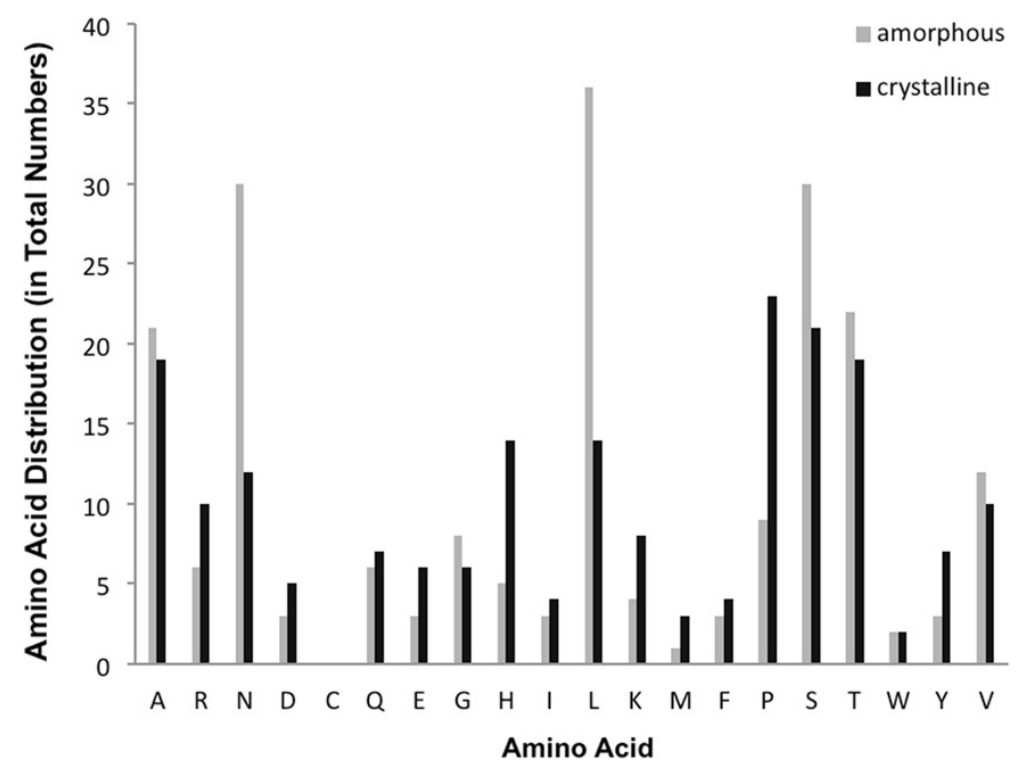

Figure 1 Amino acid distribution of the isolated peptide sequences. A total of 15 peptide sequences were analysed for amorphous $\mathrm{Ni}_{3} \mathrm{~B}$ (grey bars) and a total of 28 peptide sequences were analysed for crystalline $\mathrm{Ni}_{3} \mathrm{~B}$ (black bars).

are approximately $1 \mu \mathrm{m}$ in length and $6.5 \mathrm{~nm}$ in height. This cross section and length of the modified phage correspond to that of M13 wt phage (data not shown). Some phage were oriented with their ends towards a nanoparticle (see arrows in Figure 4), which implies an affinity between the modified phage proteins and the particle. There are a few particles that seem to be attached to the unmodified side of the phage. Possible explanations for this observation include unspecific interaction or the presence of more than one phage, i.e. bundles of phage where the end of one phage coincides with the side of another phage. A small level of unspecific interaction between nanoparticles and phage cannot be avoided during preparation for AFM imaging. The phage oriented with their ends towards the nanoparticles, suggest that the peptide LGFREKE interacts with both amorphous and crystalline $\mathrm{Ni}_{3} \mathrm{~B}$ nanoparticles.

\section{Conclusions}

Metal borides are inorganic solids that are very interesting due to their high versatility in physical properties, as for example magnetism, electrical and thermal conductivity, hardness and catalytic activity, but at the same time they are difficult to prepare. Besides the application as catalysts in all kinds of reduction reactions, and hydrogenation reactions, metallic borides are employed for the generation of conductive ceramics, hard magnets, superconductors, and hard materials [9-15,38-40]. Typical synthesis routes employ high reaction temperatures and do not allow for a directed synthesis of particles that are well-defined in terms of size, shape, uniformity, phase purity, or crystallinity.
Formation of metal boride nanoparticles in solvents has been described occasionally, but an interaction of borides with biological material or bio-molecules like peptides was unknown before $[4,5]$. To the best of our knowledge, the present study is the first to identify peptides that bind specifically to amorphous and to crystalline $\mathrm{Ni}_{3} \mathrm{~B}$ nanoparticles. Although all identified peptide sequences showed no significant binding motif, the analysis of the resulting $\mathrm{Ni}_{3} \mathrm{~B}$-binding sequences found them to be enriched in charged amino acids. The identified binding sequences possessed approximately three times more positively charged than negatively charged amino acids which leads to the assumption of electrostatic interactions between the identified binding peptides and the $\mathrm{Ni}_{3} \mathrm{~B}$ substrates. Fluorescence microscopy and AFM studies directly confirmed the adhesion of the best binding phage displaying the peptide LGFREKE to amorphous and crystalline $\mathrm{Ni}_{3} \mathrm{~B}$ particles. The best binding peptide sequence could play an important role for the development of a new synthesis route of $\mathrm{Ni}_{3} \mathrm{~B}$ in the presence of phage displaying the peptide, or the synthetic peptide, respectively, which would represent a complete new approach. The synthesis of $\mathrm{Ni}_{3} \mathrm{~B}$ in the presence of LGFREKE could result in mono-disperse and peptide capped nanoparticles with well-defined and uniform sizes and shapes exhibiting new catalytic and magnetic properties. Furthermore, the utilisation of M13 phage as template for the $\mathrm{Ni}_{3} \mathrm{~B}$ mineralisation could potentially serve as a viable alternative to create tailor-made boride composite materials by a biologically driven nano-assembly synthesis and structuring for the generation of thermoelectric devices and field effect transistors. 

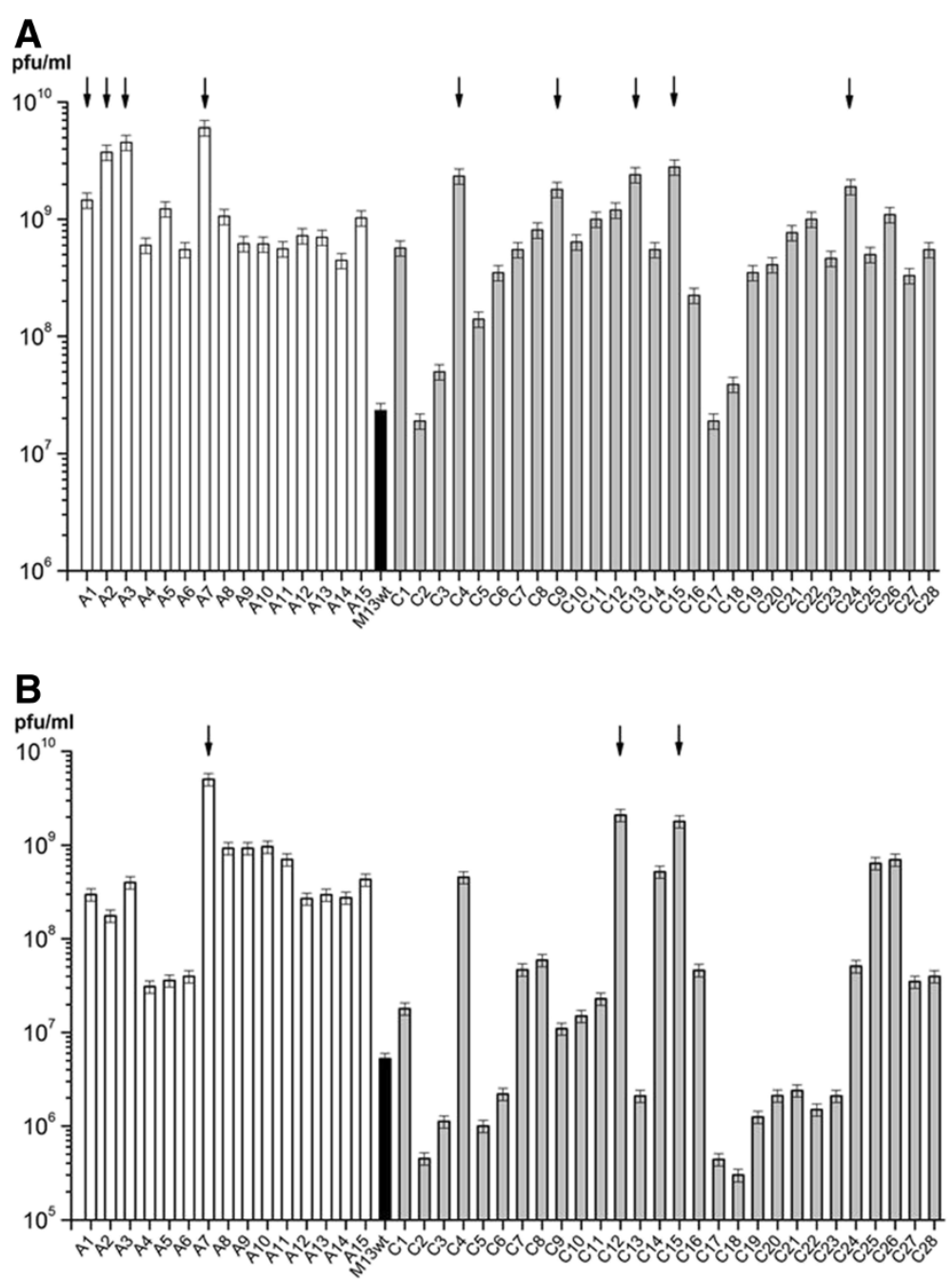

Figure 2 Evaluation of the binding strength of each of the $\mathbf{4 2}$ identified phage clones. The relative binding affinity of the phage clones to amorphous (A) and crystalline (B) $\mathrm{Ni}_{3} \mathrm{~B}$ nanoparticles was determined by titer assays at $\mathrm{pH}$ 7. The assay was repeated three-times for each clone and the elucidated phage amounts were arithmetically averaged. As a control, M13KE wild-type (M13wt) phage without a random peptide insert were compared in the same manner as the phage clones. Strong binding phage clones (>10 $\mathrm{pfu} / \mathrm{ml})$ are indicated with an arrow. Clones identified on amorphous $\mathrm{Ni}_{3} \mathrm{~B}$ are designated with an $\mathrm{A}$, clones identified on crystalline $\mathrm{Ni}_{3} \mathrm{~B}$ are designated with a $\mathrm{C}$.

\section{Methods}

\section{Phage and bacteria strains}

Recombinant M13 phage from the Ph.D.-7 heptapeptide library (New England Biolabs, MA) were amplified and propagated in the E. coli host strain ER2738 (F', lacl ${ }^{q}$, $\Delta\left(\right.$ lacZ) M15, proA ${ }^{+} B^{+}, z z f:: \operatorname{Tn} 10\left(\mathrm{Tet}^{\mathrm{R}}\right) / f h u A 2$, supE, thi-1, $\Delta($ lac-proAB $\left.), \quad \Delta(h s d S-m c r B) 5, \quad\left[\mathrm{r}_{\mathrm{k}}^{-} \mathrm{m}_{\mathrm{k}}^{-} M c r B C^{-}\right]\right)$, as described by the manufacturer. M13KE wild-type (M13wt) phage was used for the determination of unspecific binding to the $\mathrm{Ni}_{3} \mathrm{~B}$ targets. Bacteria cultures were maintained in lysogeny broth (LB) [41].

\section{Peptide library screening}

$\mathrm{Ni}_{3} \mathrm{~B}$-binding peptides were identified using a commercially available M13 bacteriophage display library (Ph.D.-7;
New England Biolabs) with random 7-mer peptides. The DNA sequences of the 7-mer peptides are N-terminal fusions to the minor coat protein $\mathrm{p} 3$ of the bacteriophage M13. A short linker sequence (GGGS) separates each random peptide from the minor coat protein $\mathrm{p} 3$. The phage display library consists of approximately $1.28 \times 10^{9}$ different peptides. The target binding, elution, and phage amplification steps were conducted according to the manufacturer's instructions. $20 \mathrm{mg}$ of amorphous or crystalline $\mathrm{Ni}_{3} \mathrm{~B}$ nanoparticles were used as targets. The targets were washed three-times with Tris-buffered saline (TBS, $50 \mathrm{mM}$ Tris- $\mathrm{HCl}, \mathrm{pH} 7$, and $150 \mathrm{mM} \mathrm{NaCl}$ ) and blocked with TBS supplemented with $5 \mathrm{mg} / \mathrm{ml}$ of BSA for 1 hour. The blocked targets were then washed three-times with TBS. To each target, a total number of $2 \times 10^{11}$ phage in 
Table 4 Strong binders identified by relative binding affinity experiments

\begin{tabular}{|c|c|c|c|c|c|}
\hline \multicolumn{6}{|c|}{$\mathrm{Ni}_{3} \mathrm{~B}$ amorphous target } \\
\hline$\#$ & Peptide & Frequency & Phage titer (pfu/ml) & Sequence & $\mathrm{pl}$ \\
\hline 1 & A7 & $1 / 30$ & $6.1 \times 10^{9}$ & LGFREKE & 6.14 \\
\hline 2 & A3 & $4 / 30$ & $4.6 \times 10^{9}$ & SLAVSRS & 9.47 \\
\hline 3 & A2 & $6 / 30$ & $3.8 \times 10^{9}$ & G A L P N N L & 5.52 \\
\hline 4 & C15 & $1 / 28$ & $2.8 \times 10^{9}$ & LEQTPMF & 4.00 \\
\hline 5 & C13 & $1 / 28$ & $2.4 \times 10^{9}$ & GPVNHQL & 6.74 \\
\hline 6 & C4 & $1 / 28$ & $2.4 \times 10^{9}$ & VPIPYLP & 5.49 \\
\hline 7 & C24 & $1 / 28$ & $1.9 \times 10^{9}$ & SPSTHWK & 8.49 \\
\hline 8 & C9 & $1 / 28$ & $1.8 \times 10^{9}$ & SASKVHN & 8.49 \\
\hline 9 & A1 & $8 / 30$ & $1.5 \times 10^{9}$ & TNLTLAS & 5.19 \\
\hline \multicolumn{6}{|c|}{$\mathrm{Ni}_{3} \mathrm{~B}$ crystalline target } \\
\hline$\#$ & Peptide & Frequency & Phage titer (pfu/ml) & Sequence & $\mathrm{pl}$ \\
\hline 1 & A7 & $1 / 30$ & $5.1 \times 10^{9}$ & LGFREKE & 6.14 \\
\hline 2 & C12 & $1 / 28$ & $2.1 \times 10^{9}$ & Y Q V V P A R & 8.75 \\
\hline 3 & C15 & $1 / 28$ & $1.8 \times 10^{9}$ & LEQTPMF & 4.00 \\
\hline
\end{tabular}

$1 \mathrm{ml}$ of TBS with $0.1 \%$ Tween-20 (0.1\% TBST) were incubated for 1 hour. Non-specifically or weakly bound phage particles were removed by washing ten-times with $0.1 \%$ TBST. The remaining bound phage particles were eluted with a solution containing $0.2 \mathrm{M}$ glycine- $\mathrm{HCl}, \mathrm{pH} 2.2$ and $1 \mathrm{mg} / \mathrm{ml} \mathrm{BSA}$. After centrifugation, the supernatant was removed from the target and neutralised with $1 \mathrm{M}$ of Tris$\mathrm{HCl}, \mathrm{pH}$ 9. The eluted phage were amplified through infection into E. coli ER2738, followed by purification by precipitation with polyethylene glycol according to the manufacturer's instructions. This completed a round of panning. The entire biopanning process was repeated five rounds to enrich for tight binders. To inhibit the hydrophobic interactions between the phage library and the $\mathrm{Ni}_{3} \mathrm{~B}$ targets, the concentration of Tween- 20 was successively increased in each panning step from $0.1 \%, 0.3 \%$, $0.5 \%, 0.6 \%$, and $0.8 \%$, respectively. After the fourth and fifth

Table 5 Competitive binding assay results for amorphous $\mathrm{Ni}_{3} \mathrm{~B}$ target

\begin{tabular}{lll}
\hline Peptide & Sequence & Frequency \\
\hline A7 & L GFREKE & $17 / 29$ \\
C24 & SPSTHWK & $3 / 29$ \\
C9 & SASKVH N & $2 / 29$ \\
C15 & LEQTP M F & $2 / 29$ \\
A1 & TNLTLA S & $1 / 29$ \\
A2 & G A L N N L & $1 / 29$ \\
C4 & VPIPYLP & $1 / 29$ \\
C13 & GPVNH Q L & $1 / 29$ \\
A3 & SLAVSRS & $0 / 29$ \\
\hline
\end{tabular}

Table 6 Competitive binding assay results for crystalline $\mathrm{Ni}_{3} \mathrm{~B}$ target

\begin{tabular}{lll}
\hline Peptide & Sequence & Frequency \\
\hline A7 & L GFREKE & $13 / 29$ \\
C9 & SASKVH N & $5 / 29$ \\
C24 & SPSTHWK & $5 / 29$ \\
C13 & GPVNH Q L & $4 / 29$ \\
C4 & VPIPYLP & $1 / 29$ \\
C15 & LE Q TPM F & $1 / 29$ \\
A1 & TNLTLA S & $0 / 29$ \\
A2 & G A L P N L & $0 / 29$ \\
A3 & SLAVSRS & $0 / 29$ \\
\hline
\end{tabular}

round of screening, the eluted phage were diluted and titrated on LB agar plates containing 5-bromo-4-chloro-3indolyl $\beta-\mathrm{D}$-galactopyranoside (Xgal) and isopropyl- $\beta$-Dthiogalactopyranosid (IPTG). A total of 58 randomly selected phage plaques, which appeared blue, were picked and analysed by DNA sequencing. The phage titer was determined by titration according to manufacturer's recommendations using appropriate dilutions of the precipitated phage.

\section{Binding affinity assays}

The binding affinity of each identified phage clone with the $\mathrm{Ni}_{3} \mathrm{~B}$ substrates was demonstrated by mixing equivalent phage amounts $\left(1 \times 10^{10} \mathrm{pfu} / \mathrm{ml}\right)$ of individual phage clones with either $20 \mathrm{mg}$ of amorphous or crystalline $\mathrm{Ni}_{3} \mathrm{~B}$ nanoparticles in $1 \mathrm{ml}$ of TBS containing 0.8\% Tween-20. After 1 hour incubation at room temperature the unbound phage were removed by washing the substrates ten-times. Bound phage were then isolated using the standard acidic elution method as used in the screening procedure. For each clone, the bound phage amount was elucidated by titration according to manufacturer's recommendations using appropriate dilutions of the eluted phage. The binding strength of a single clone directly correlates with the phage titer of the eluted phage. The assay was repeated three-times for each clone and the elucidated phage titers were arithmetically averaged. M13KE wild-type phage, with no random peptides displayed on the p3 protein, was used as a control.

\section{Competitive binding assays}

The phages with the highest binding affinity to either amorphous or crystalline $\mathrm{Ni}_{3} \mathrm{~B}$ were evaluated by the method of a competitive binding assay. For this assay, the individual phage clones of the nine strongest binders on amorphous $\mathrm{Ni}_{3} \mathrm{~B}$ as determined by binding affinity assays, were separately amplified and diluted into a mini-phage library at a concentration of $1 \times 10^{7} \mathrm{pfu} / \mu \mathrm{l}$ per clone. Subsequently $1 \times 10^{10} \mathrm{pfu} / \mathrm{ml}$ of this minimised phage library was applied to amorphous or crystalline $\mathrm{Ni}_{3} \mathrm{~B}$ nanoparticles 


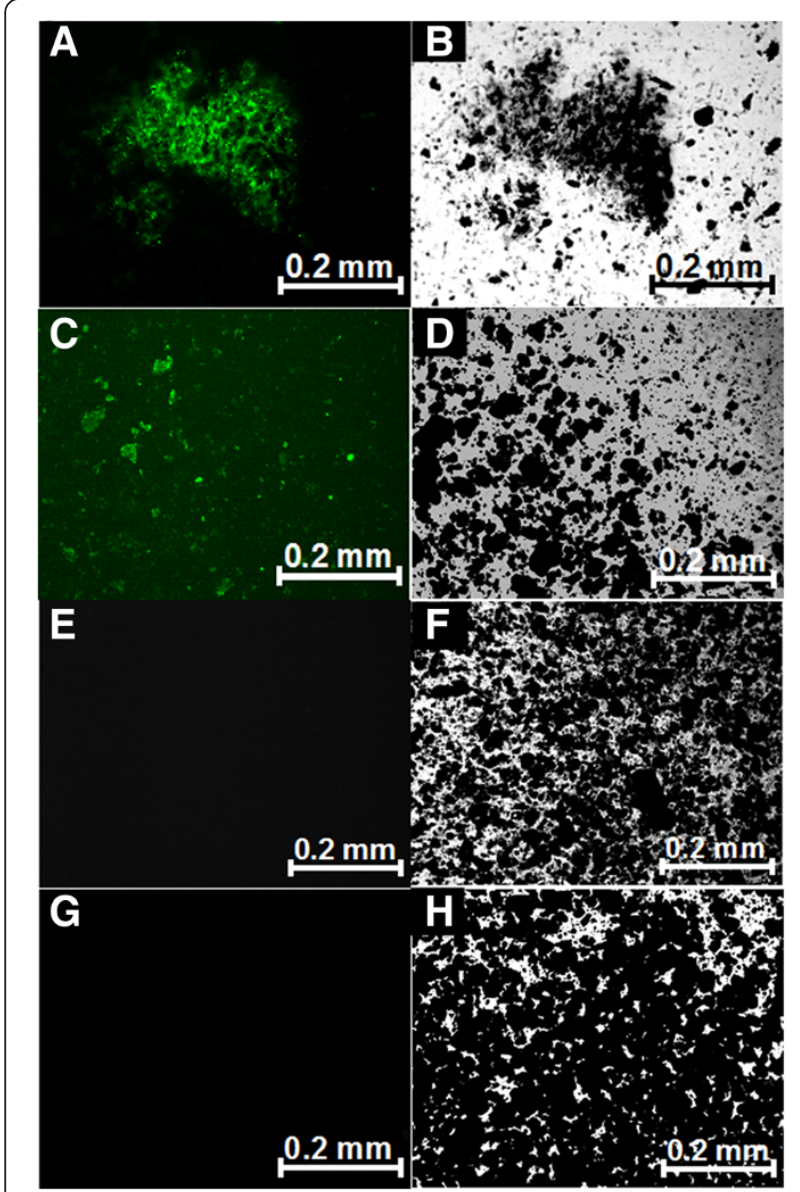

Figure 3 Analysis of the phage binding by fluorescence microscopy. Confocal fluorescence $(\mathbf{A}, \mathbf{C})$ and transmission optical microscopy (B, D) of LGFREKE phage bound to amorphous (A, B) and crystalline (C, D) $\mathrm{Ni}_{3} B$ nanoparticles. The samples were dyed using a fluorescently tagged anti-M13 monoclonal antibody. Confocal fluorescence $(\mathbf{E}, \mathbf{G})$ and transmission optical microscopy $(\mathbf{F}, \mathbf{H})$ of the control experiments of amorphous and crystalline $\mathrm{Ni}_{3} \mathrm{~B}$ nanoparticles, respectively, which were preincubated with M13KE wild-type (M13wt) phage before incubation with the fluorescently tagged antibody.

as described for the procedure of the binding affinity assays. After a single panning round, the weakly bound phages were removed by washing the substrates and the remaining strongly bound phages were isolated using the standard acidic elution method as used in the screening procedure. The eluted phages were quantified by titration according to the manufacturer's recommendations. The assay was repeated three-times for each substrate. A total number of 29 plaques were randomly picked for each substrate and sequenced to reveal the most strongly binding peptide sequences.

\section{Synthesis and characterisation of amorphous and} crystalline $\mathrm{Ni}_{3} \mathrm{~B}$

The $\mathrm{Ni}_{3} \mathrm{~B}$ nanoparticles were synthesised from $\mathrm{NaBH}_{4}$ (Alfa Aesar, 97\%) and $\mathrm{NiCl}_{2} \times 6 \mathrm{H}_{2} \mathrm{O}$ (Grüssing $\mathrm{GmbH}$,
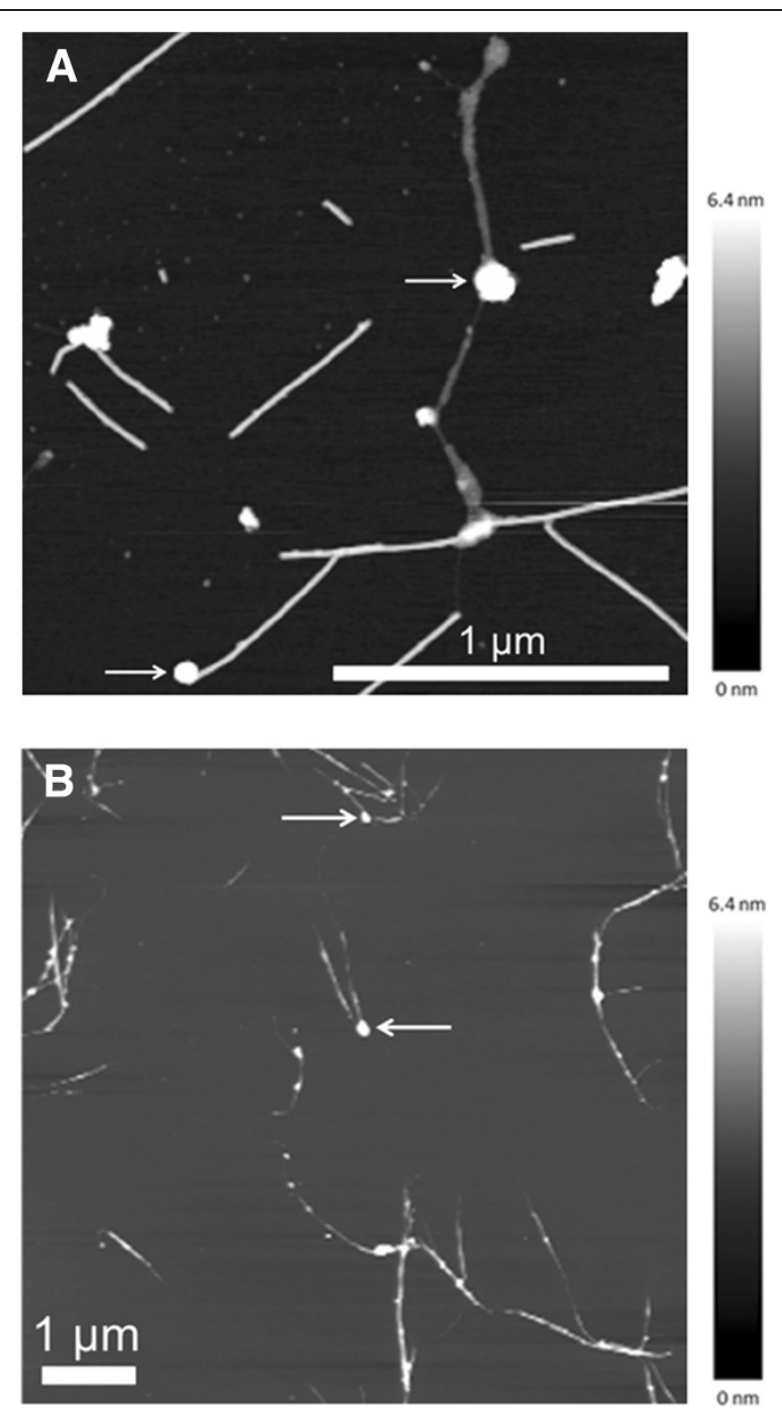

Figure 4 Visualisation of the phage binding by atomic force microscopy. Topographic AFM images of the binding of modified M13 phage (LGFREKE) to amorphous (A) and crystalline (B) $\mathrm{Ni}_{3} \mathrm{~B}$ nanoparticles. The AFM images of M13 phage displaying the A7 peptide on $\mathrm{p} 3$ showed the phage to bind to several amorphous and crystalline $\mathrm{Ni}_{3} \mathrm{~B}$ nanoparticles at the tip of $\mathrm{p} 3$, which are indicated by arrows. The colour scale exceeds the particle height to better display the particle cross section.

98\%) in aqueous solution at about $0^{\circ} \mathrm{C}$ following a synthesis route described earlier [5]. According to this procedure amorphous $\mathrm{Ni}_{3} \mathrm{~B}$ is formed primarily, which is transformed into the crystallised $\mathrm{Ni}_{3} \mathrm{~B}$ sample at $490^{\circ} \mathrm{C}$ in vacuum $\left(5 \times 10^{-3} \mathrm{mbar}, 18 \mathrm{~h}\right)$. The X-ray diffraction pattern of the annealed, crystalline sample allows for its identification as $\mathrm{Ni}_{3} \mathrm{~B}$ (see Additional file 1). In previous work, we have shown using methods like X-ray diffraction, energydispersive X-ray spectroscopy, X-ray absorption spectroscopy, scanning and transmission electron microscopy, and energy-loss electron spectroscopy that the corresponding amorphous phase actually consists of the same boride as 
the crystalline modification [5,7]. For the phage display the amorphous $\mathrm{Ni}_{3} \mathrm{~B}$ nanoparticles were used after extensive washing with deionized water and drying in a desiccator under vacuum. The crystalline nanoparticles were obtained from the amorphous product after the annealing process and used directly.

\section{Fluorescence microscopy analysis}

The binding of M13 phage to amorphous and crystalline nickel boride nanoparticles was characterised with a Zeiss Axiovert 200 inverted fluorescence microscope equipped with a Zeiss AxioCam HRm. The fluorescence images were taken using emission at $528 \mathrm{~nm}$. M13 phage were incubated with $10 \mathrm{mg}$ of amorphous and crystalline $\mathrm{Ni}_{3} \mathrm{~B}$ nanoparticles at a concentration of $3 \times 10^{12} \mathrm{pfu} / \mathrm{ml}$ in $1 \mathrm{ml}$ TBS supplemented with $0.8 \%$ Tween-20. After $2 \mathrm{~h}$ at room temperature, unbound phage were removed by washing the substrates three-times with TBS. Subsequently, the substrates were blocked with TBS supplemented with $2 \%$ BSA and $0.05 \%$ Tween-20 for 1 hour and washed three-times with TBS supplemented with $0.05 \%$ Tween- 20 . The samples were dyed using a FITC tagged anti-M13 monoclonal antibody against phage coat protein p8 (Acris Antibodies, Inc., Herford, Germany). Each target was incubated for 1 hour with $1 \mu \mathrm{g} / \mathrm{ml}$ of labeled monoclonal antibodies in TBS with $0.05 \%$ Tween-20. After removing unbound antibodies by washing the samples three-times with TBS containing $0.05 \%$ Tween-20, the samples were analysed by fluorescence microscopy.

\section{Atomic force microscopy (AFM) analysis}

$\mathrm{Ni}_{3} \mathrm{~B}$ nanoparticles, phages and compounds of phages with $\mathrm{Ni}_{3} \mathrm{~B}$ were characterised with an atomic force microscope (AFM). The measurements were carried out on a Dimension Icon AFM with a Nanoscope V controller (Bruker, Santa Barbara, California) in ambient conditions. The measurements were performed in tapping mode, to minimise the lateral interaction. Silicon cantilevers (PPP NCH, Nanosensors) with a nominal resonance frequency of $330 \mathrm{kHz}$, spring constant of $42 \mathrm{Nm}^{-1}$, and a nominal tip diameter of less than $10 \mathrm{~nm}$ were used. All images were taken at a resolution of $512 \times 512$ pixel $^{2}$. M13 phages were incubated with $10 \mathrm{mg}$ of amorphous and crystalline $\mathrm{Ni}_{3} \mathrm{~B}$ nanoparticles at a concentration of $3 \times 10^{12} \mathrm{pfu} / \mathrm{ml}$ in $1 \mathrm{ml}$ TBS supplemented with $0.8 \%$ Tween-20. After $2 \mathrm{~h}$, unbound phages were removed by washing the substrates threetimes with TBS. Samples were prepared by dropping the sample suspension on a silicon wafer or freshly cleaved mica. The samples were dried in a stream of dry nitrogen. Image analysis and processing was performed with the Nanoscope Analysis software Version 1.40 (Bruker). A plane correction procedure and a line by line fit were used to compensate for the sample tilt.

\section{Additional file}

Additional file 1: X-ray powder diffraction profile. Calculated (solid blue line) and difference (solid red line) $X$-ray powder diffraction profiles for the Rietveld refinement of crystalline $\mathrm{Ni}_{3} \mathrm{~B}$. Reflection positions are marked (blue bars)

\section{Competing interests}

The authors declare that they have no competing interests.

\section{Authors' contributions}

SJF and MP drafted the manuscript. $\mathrm{CB}$ and $\mathrm{KH}$ synthesised the $\mathrm{Ni}_{3} \mathrm{~B}$ substrates for the use in biopanning. MP identified and characterised the binding peptides, and visualised the adhesion of the phage by fluorescence microscopy. LZ did the AFM analysis of $\mathrm{Ni}_{3} \mathrm{~B}$ nanoparticles, phages and compounds of phages with $\mathrm{Ni}_{3} \mathrm{~B}$. BA, SJF, RWS, and BH planned and designed this project. SJF, MP and BA read and approved the final manuscript. All authors read and approved the final manuscript.

\section{Acknowledgements}

This work was supported by the Deutsche Forschungsgemeinschaft (DFG) under grant HA 1251/2-1, STA 1026/5-1, and AL 536/11-1 as part of the Priority Programme SPP 1569 "Generation of multifunctional inorganic materials by molecular bionics".

\section{Author details}

${ }^{1}$ Institute of Technical Biochemistry, University of Stuttgart, Allmandring 31, 70569 Stuttgart, Germany. ${ }^{2}$ Eduard-Zintl-Institute of Inorganic and Physical Chemistry, Technische Universität Darmstadt, Alarich-Weiss-Str. 12, 64287 Darmstadt, Germany. ${ }^{3}$ Center of Smart Interfaces, Physics of Surfaces and Institute of Materials Sciences, Technische Universität Darmstadt, Alarich-Weiss-Str. 10, 64287 Darmstadt, Germany.

Received: 31 May 2013 Accepted: 29 January 2014 Published: 10 February 2014

\section{References}

1. Schwarzkopf P, Kieffer R: Refractory Hard Metals. 1st edition. The Macmillan Company: New York; 1953:311-312.

2. Buzea C, Yamashita T: Review of the superconducting properties of $\mathrm{MgB}_{2}$. Supercond Sci Technol 2001, 14:R115-R146.

3. Herbst JF, Croat JJ: Neodymium-iron-boron permanent magnets. J Magn Magn Mater 1991, 100:57-78

4. Brown HC, Brown CA: New, highly active metal catalysts for the hydrolysis of borohydride. J Am Chem Soc 1962, 84:1493-1494.

5. Kapfenberger C, Hofmann K, Albert A: Room-temperature synthesis of metal borides. J Solid State Sci 2003, 5:925-930.

6. Caputo R, Guzzetta F, Angerhofer A: Room-temperature synthesis of nickel borides via decomposition of $\mathrm{NaBH}_{4}$ promoted by nickel bromide. Inorg Chem 2010, 49:8756-8762.

7. Rades S, Kornowski A, Weller H, Albert B: Wet-chemical synthesis of nanoscale iron boride. Chem Phys Chem 2011, 12:1756-1760.

8. Chen CL, Rosi NL: Peptide-based methods for the preparation of nanostructured inorganic materials. Angew Chem Int Ed 2010, 49:1924-1942.

9. Boar RB, Hawkins DW, McGhie JF, Barton DHR: Some applications of nickel boride as a desulphurising agent. An improved route to triterpene 2-enes. J Chem Soc, Perkin Trans 1973, 1:654-657.

10. Sarma DN, Sharma RP: Nickel boride reductive cleavage of allylic trimethylsilyl ethers. Tetrahedr Lett 1985, 26:371-372.

11. Seltzmann $\mathrm{HH}$, Berrang BD: Nickel boride reduction of aryl nitro compounds. Tetrahedr Lett 1993, 34:3083-3086.

12. Molvinger K, Lopez M, Court J: Enantioselective borane reduction of ketones with oxazaborolidines boron-bound to nickel boride nanoparticles. Tetrahedr Lett 1999, 40:8375-8378.

13. Saxena I, Borah R, Sarma JC: Reductive amination of aromatic aldehydes and ketones with nickel boride. J Chem Soc, Perkin Trans 2000, 1:503-504

14. Brown CA: Catalytic hydrogenation. V. The reaction of sodium borohydride with aqueous nickel salts. P-1 nickel boride, a convenient, 
highly active nickel hydrogenation catalyst. J Org Chem 1970, 35:1900-1904.

15. Pavlik JW: Catalytic hydrogenation using nickel boride. J Chem EduC 1972, 49:528.

16. Bratkovsky AM, Rashkeev SN, Wendin G: Electronic structure, ferromagnetism, and EELS spectra of crystalline alloys FenB and NinB ( $n=1,2,3)$ : Aspects of universal behavior. Phys Rev B 1993, 48:6260-6270.

17. Schaefer ZL, Ke X, Schiffer P, Schaak RE: Direct solution synthesis, reaction pathway studies, and structural characterization of crystalline $\mathrm{Ni}_{3} \mathrm{~B}$ nanoparticles. J Phys Chem C 2008, 112:19846-19851.

18. Sarikaya M, Tamerler C, Jen AKY, Schulten K, Baneyx F: Molecular biomimetics: nanotechnology through biology. Nat Mater 2003, 2:577-585.

19. Baneyx F, Schwartz DT: Selection and analysis of solid-binding peptides. Curr Opin Biotechnol 2007, 18:312-317.

20. Whyburn GP, Li Y, Huang Y: Protein and protein assembly based material structures. J Mater Chem 2008, 18:3755-3762.

21. Smith GP, Petrenko VA: Phage Display. Chem Rev 1997, 97:391-410.

22. Naik RR, Stringer SJ, Agarwal G, Jones SE, Stone MO: Biomimetic synthesis and patterning of silver nanoparticles. Nat Mater 2002, 1:169-172.

23. Heinz H, Farmer BL, Pandey RB, Slocik JM, Patnaik SS, Pachter R, Naik RR: Nature of molecular interactions of peptides with gold, palladium, and Pd-Au bimetal surfaces in aqueous solution. J Am Chem Soc 2009, 131:9704-9714.

24. Umetsu M, Mizuta M, Tsumoto K, Ohara S, Takami S, Watanabe H, Kumagai I, Adschiri T: Bioassisted room-temperature immobilization and mineralization of zinc oxide - The structural ordering of $\mathrm{ZnO}$ nanoparticles into a flower-type morphology. Adv Mater 2005, 17:2571-2575.

25. Rothenstein D, Claasen B, Omiecienski B, Lammel P, Bill J: Isolation of ZnObinding 12-mer peptides and determination of their binding epitopes by NMR spectroscopy. J Am Chem Soc 2012, 134:12547-12556.

26. Naik RR, Brott LL, Clarson SJ, Stone MO: Silica-precipitating peptides isolated from a combinatorial phage display peptide library. J Nanosci Nanotechnol 2002, 2:95-100.

27. Dickerson MB, Jones SE, Cai Y, Ahmad G, Naik RR, Kröger N, Sandhage KH: Identification and design of peptides for the rapid, high-yield formation of nanoparticulate $\mathrm{TiO}_{2}$ from aqueous solutions at room temperature. Chem Mater 2008, 20:1578-1584.

28. Lee SW, Mao C, Flynn CE, Belcher AM: Ordering of quantum dots using genetically engineered viruses. Science 2002, 296:892-895.

29. Flynn CE, Mao CB, Hayhurst A, Williams JL, Georgiou G, Iverson B, Belcher AM: Synthesis and organization of nanoscale II-VI semiconductor materials using evolved peptide specificity and viral capsid assembly. $J$ Mater Chem 2003, 13:2414-2421.

30. Dong J, Chuan L, Zhang J, Xin ZT, Yang G, Gao B, Mao CQ, Liu NL, Shao NS, Fan M, Xue YN: Selection of novel nickel-binding peptides from flagella displayed secondary peptide library. Chem Biol Drug Des 2006, 68:107-112.

31. Chung KCC, Cao L, Dias AV, Pickering IJ, George GN, Zamble DB: A highaffinity metal-binding peptide from Escherichia coli HypB. J Am Chem Soc 2008, 130:14056-14057.

32. Zoroddu MA, Medici S, Peana M: Copper and nickel binding in multihistidinic peptide fragments. J Inorg Biochem 2009, 103:1214-1220.

33. Thomas CJ, Sharama S, Kumar G, Visweswariah SS, Surolia A: Biopanning of endotoxin-specific phage displayed peptides. Biochem Biophys Res Commun 2003, 307:133-138.

34. Okamoto $Y$, Nitta $Y$, Imanaka T: Surface characterisation of nickel boride and nickel phosphide catalysts by X-ray photoelectron spectroscopy. J Chem Soc, Faraday Trans 1978, 1:2027-2039.

35. Jaworski JW, Raorane D, Huh JH, Majumdar A, Lee SW: Evolutionary screening of biomimetic coatings for selective detection of explosives. Langmuir 2008, 24:4938-4943.

36. Willett RL, Baldwin KW, West KW, Pfeiffer LN: Differential adhesion of amino acids to inorganic surfaces. PNAS 2005, 102:7817-7822.

37. Amaral M, Lopes MA, Santos JD, Silva RF: Wettability and surface charge of $\mathrm{Si}_{3} \mathrm{~N}_{4}$-bioglass composites in contact with simulated physiological liquids. Biomaterials 2002, 23:4123-4129.

38. Fahrenholtz WG, Hilmas GE, Talmy IG, Zaykoski JA: Refractory diborides of zirconium and hafnium. J Am Ceram Soc 2007, 90:1347-1364.
39. Brown D, Ma B-M, Chen Z: Developments in the processing and properties of NdFeB-type permanent magnets. J Magn Magn Mater 2002, 248:432-440.

40. Nagamatsu J, Nakagawa N, Muranaka T, Zenitani Y, Akimitsu J: Superconductivity at $39 \mathrm{~K}$ in magnesium diboride. Nature 2001, 410:63-64.

41. Bertani G: Studies on lysogenesis. I. The mode of phage liberation by lysogenic Escherichia coli. J. Bacteriol 1951, 62:293-300.

doi:10.1186/1472-6750-14-12

Cite this article as: Ploss et al: Selection of peptides binding to metallic borides by screening M13 phage display libraries. BMC Biotechnology 2014 14:12

\section{Submit your next manuscript to BioMed Central and take full advantage of:}

- Convenient online submission

- Thorough peer review

- No space constraints or color figure charges

- Immediate publication on acceptance

- Inclusion in PubMed, CAS, Scopus and Google Scholar

- Research which is freely available for redistribution 